\title{
The Application of the Craftsmanship Spirit in Quality-oriented Education of Students in Vocational Colleges
}

\author{
Yan Han \\ Jiangsu province xuzhou technician institute \\ Xuzhou, Jiangsu 221151, China \\ 1030638329@qq.com
}

\begin{abstract}
The educational target of vocational colleges is to train applied talents with certain cultural level, professional knowledge and skills, and comprehensive qualities in order to meet the needs of individual employment and the demands of jobs, and then promote the development of social productivity. As the theme of the moving story of ordinary laborers, the craftsmanship spirit, published by Ministry of Human Resources and Social Security, vividly illustrates craftsmanship spirit, and points out the direction for the training of skilled personnel in vocational colleges. Based on the interpretation of the craftsmanship spirit, this paper proposes to implement the craftsmanship spirit and promote the comprehensive qualities of students by setting up activities at different levels, regulating students' civilized behaviors from details, cultivating craftsmen's mentors, and following up the process of cooperation between schools and enterprises.
\end{abstract}

Keywords-Vocational colleges; Quality-oriented education; Craftsmanship spirit

\section{INTRODUCTION}

The "craftsman's spirit" is composed of two words with specific significance, "craftsman" and "spirit", which has the double meaning of "craftsman" and "consciousness"[1]. The craftsman in the new period is not only the mechanical worker, but must have the quality of firmness, sureness and the will for perfection. In craftsman's spirit, hardship endurance spirit is the premise, but to bear hardships is not simply to work hard and sweat, but also to be intelligent, diligent and innovative, to do things others are not willing to do, and to do it more carefully and better. As the main position of skilled personnel training, vocational colleges have attached great importance to the training of students' comprehensive quality and gradually integrated into the education elements of craftsman's spirit for many years [2]. In order to achieve the goal of educating students better, this paper puts forward some considerations as follows.

\section{PAY ATTENTION TO THE CONSTRUCTION OF SPIRITUAL CULTURE AND FORM THE CRAFTSMAN ENVIRONMENT}

In order to infiltrate further the "craftsman's spirit" into the vocational colleges, it is necessary to construct an imperceptibly environmental culture on campus, which can influence the students' craftsman consciousness. First, the educational philosophy. The principle of a school together with its ethos, its motto, its teaching objectives, and its teaching strategies has a strong sense of centripetal force and appeal to students. It can even affect a whole industry. For example, the school motto of Beijing Normal University is "Learn to be an Excellent Teacher, Act as an Exemplary Person" and "Train to Win" is the motto of Special Military School of St Cyr. For vocational colleges, it is the fundamental task to train qualified talents for the society. It is necessary to help students to strengthen their belief in becoming a useful person by skills. It is important to let the students know that though diploma is important, the college entrance examination is not a single-log bridge of life, everyone can glow and shine as long as he or she has a professional skill. Second, campus culture. Campus culture includes many aspects, such as institutional culture, environmental culture, custom culture, competition culture, etc. For example, putting up the skills slogans, unifying working clothes, setting up the statue of Lu Ban, holding skill contests, etc., can virtually establish the cultural atmosphere of the craftsman's spirit for the students in the technical college. Third, the construction of teacher's morality. Teachers' morality level, work style and professional dedication is not only related to the teaching quality of vocational colleges. Besides, teaching by personal example is better than verbal instruction and the teacher's words and behaviors, hard work, professional spirit, and the ways of details treatment will unconsciously exert influences on the students at all times[3]. Therefore, we should pay more attention to the training and evaluation of the craftsman's spirit of the teachers, and strengthen the sense of responsibility so as to play an exemplary role to students. The school should organize teachers to train regularly and take part in practical training in the enterprise to improve teachers' comprehensive quality. 


\section{CONDUCT THEMATIC ACTIVITIES AT DIFFERENT LEVELS AND METICULOUSLY HANDLE THE DETAILS OF CRAFTSMANSHIP SPIRITS}

"Craftsman's spirit" is not only the guiding ideology, but also the work details that need to be implemented [4]. In the process of education, vocational educators should set up the principle that students are the main body, the teachers are the leading role and the student management organization is the guidance. The functional organization establishes education thesis of a term or academic year and rough time planning with a rough guide. Based on this foundation, the secondary faculty's student management organization implements the rough guide of thought, and combines the professional characteristics of its own institute with the main body of the activity to formulate a detailed activity plan that is "dispersive and inextricable" so as to highlight the effectiveness and point to the goal of educating students.

Grade level. That is, setting up activities scientifically according to the growth pattern of the students from entry to graduation: Lower- grade students focus on "shaping" activities such as "student handbook knowledge competition, housekeeping competition, campus civilization, dining civilization" and multi-tasking, tug-of-war competitions, hot wheels, relay races and other activities to enhance team cohesion. Middle-grade students focus on "traditional culture education, craftsman's spirit theme, thanksgiving education, life education, student cadre competitions, group knowledge competitions, ball leagues" and other "cultivation" activities [5]. Senior students focus on the development of "talent show, legal lecture, rights debate, corporate culture experience" and other professional characteristics-all kinds of activities with professional characteristics, comprehensive ability display, and better convergence of society.

Main body level. First of all, school-level activities planned in an integrated manner and general education are fully carried out. For national guidelines and policies, such as spiritual education, legal education, moral lecture, craftsmanship, safety education, human rights debate, sports league, manner and behavior, civilization cultivation, thanksgiving education, life education, honest education, environment protection education, etc., general education can be planned and deployed at the school level, and all students are educated according to certain plans, so as to enhance comprehensive education. Second, all the secondary faculties carry out teaching activities in combination with professional characteristics. Professional teaching and student management are not two non-intersecting parallel lines. They are closely linked and complement each other. Their ultimate direction is to educate students and have the same goal. In addition to the general education of "required" projects stipulated by the functional departments, student activities should leave "optional" room for the secondary faculties, so as to highlight professional features. On the one hand, it is to enhance professional charm and stimulate interest in learning through "promoting special education to promote learning". For example, preschool education majors can launch series of activities such as dancing competition, good voices, concerts, manual salons, "I'll be a teacher" simulation class, and "three words and one sentence"; The Culinary Specialty can launch Chinese-Western style pasta competition, I am a chef, tasting bartender and other activities; Information technology direction can host my Internet+, programming era, animation world; Architectural decoration professional can hold exhibitions, and other thematic activities such as "I am a designer" . On the other hand, the decentralization of the right to independent design of activities is more conducive to the "cute women can do with rice", thereby improving the quality of activities and even forming brand activities. Whether it is the exchange visits between colleges, or all kinds of competitions at the municipal level or above, they can be selected according to the theme so as to get twofold results with half the efforts. Third, transfer the rights of the theme activity and carry out independent personality education. Students are the objects of education and are the main body of specific activities. Fully respecting the students' subjective consciousness, fully establishing the students' main body position and fully exerting the students' main role should not be downplayed. For example, let students work as teacher assistants, principal assistants and transfer rights to students to actively plan class activities, professional activities or department activities to promote their scientific and democratic participation in school affairs management and activity design [6]. This is also an innovative attempt. It will not only cultivate the sense of students' ownership, but also improve their working ability and management levels. This in itself is an important part of vocational education.

\section{ATTACH IMPORTANCE TO STUDENT CLUBS AND SHARPEN THE CRAFTSMANSHIP SPIRIT BEHAVIOR.}

Student community is an important carrier of campus culture construction. It is not only the leader of the students' second classroom, but a voluntary and regulated mass student organization that can meet the demands of students with common interests to achieve common wishes. Vocational colleges have mostly solved the problem of students' associations from absence to variety. They have taken an important step in the construction of mass organizations, but there are also some areas that need improvement: On the one hand, the composition of student clubs can be across grades, across classes, or even across colleges; Teaching plans of club lessons can be provided in the form of an activity scheme, highlighting the purpose of the event, the idea of activities, and the analysis of the effects of activities. The evaluation of club lessons can be carried out regularly or irregularly by specialized personnel. In order to promote the development of mass organizations, various forms such as community teacher training, model observation courses, collective lesson preparation, community event tours, and community club competitions can be introduced; On the other hand, the choice of community courses based on their hobbies will lead them to delve the details with more potential and interest, and study methods, and not afraid to work hard. At last it can lead them to strive for excellence, and pursue higher quality. This is the best place to develop "craftsman's thought" behavior [7]. 


\section{ENHANCE THE CRAFTSMEN'S ACCOMPLISHMENT HABITS WITH STUDENTS' DAILY BEHAVIORAL PROCESSES.}

The essential difference between vocational education and general education is cultivating students' "behavioral orientation". In order to implement the "craftsman's spirit" into practice, we need to gradually infiltrate the management details or teaching on usual. For example, the access control system for students has certain requirements for the card's standardization. The school will record students' bad habits like careless treatment or forgetting things as disciplinary offences. The strict requirement of swiping card is to form students' carefulness and meticulous attitude and develop students' good behavior habits. For example, cultivating student's team spirit by accomplishing a group project. It is also an effective way to cultivate students" "craftsman spirit" by cultivating students' awareness of cost by proposing purchase amount in terms of the design project. For example, the gap between the finished products and the waste may be 0.01 millimeters, but hard work is not enough to make up the small gap. This requires the ability to be skilled and innovative. Only that can improve the quality of products from $99 \%$ to 99.99\% and to perfection. Of course, "craftsman spirit" not only requires hard work, but also needs the spirit of innovation. By perfecting the scientific management mode, students will accumulate in the process of operation, and make creative thinking on the basis of ingenuity, so as to cultivate their creative ability.

\section{BUILD A TEAM OF “DUAL-QUALIFIED” TEACHERS WITH BOTH MORALITIES AND ABILITIES TO LAY THE FOUNDATION FOR THE CRAFTSMAN MENTOR}

Craftsmanship is inherited from generation to generation. It is inseparable from the careful guidance of the master. The construction of today's "dual-qualified" teaching staff is a modernized representation of traditional teachers. Therefore, the dual-qualified teachers with both ability and morality are indispensable for cultivating vocational qualifications of vocational college students. The role of the teacher is to impart reason and solve doubts. For vocational education, teachers should have both professional knowledge and professional qualities, guide students through dual roles and participate in the entire education and teaching process. "Dual-qualified" teachers should do the following three things: The first is to establish the correct concept of professionalism, that is, to have practical experience in the enterprise. Under the premise of understanding the market demand, the company's cultural literacy and teaching of the school's theoretical knowledge should be closely integrated into the teaching process. Teachers should be guided by this idea and strive to cultivate the professionalism of vocational college students. The second is to study related theories of vocational education in training, and follow the rules of individual growth and development of teachers and in the same time, improve their professionalism in training. Third, teachers should change teaching methods, focus on experiential teaching, use a variety of teaching methods, set up appropriate situations, ensure that all students participate in them, enhance the interaction between teachers and students and mobilize the enthusiasm of students.

\section{FOLLOW UP THE COOPERATION PROCESS BETWEEN THE SCHOOL AND ENTERPRISES AND REALIZE THE "CRAFTSMAN SPIRIT"}

School-enterprise cooperation is employment-oriented and is one of the important ways that our country strongly encourages to cultivate the professional qualities of vocational college students. When implementing school-enterprise cooperation, vocational colleges should pay attention to three aspects: First, vocational colleges have always been the main fronts for training students. They should not push their responsibilities and work to enterprises and should not think that as long as companies deeply participate, they can achieve the desired results. Especially during student internships, vocational colleges should still manage and cooperate with the enterprise and comprehensively participate in the whole process from selection to evaluation feedback. The second is to integrate the essence of corporate culture with campus culture. Vocational colleges should learn more from the excellent culture of enterprises. In enterprises, the craftsman spirit is reflected all the time. The students should try to feel the cultural atmosphere of the enterprise, accumulate work experience in the real enterprise environment, understand the value of the profession, improve the sense of professional identity and cultivate the professional consciousness of the students. Vocational colleges must understand the requirements of the enterprise, cultivate students strictly by the standardization of enterprise behavior and operating rules, make the students correct their professional attitude, learn to internalize their responsibilities, make them have a high sense of responsibility and gradually form the characteristics of dedication, excellence and hard work in practice and cultivate the students' professional attitude and professional ethics. Craftsman comes from the front line and from enterprises. The cultivation of professional quality of vocational college students must be integrated into enterprises. The school should cultivate excellent and skilled talents with school enterprise cooperation mode.

\section{CONCLUSION}

The cultivation of professionalism is not simply preparing for employment, but preparing for life. In the context of the community's strong call for craftsmanship, vocational colleges should adopt various measures to cultivate students' professional qualities, make them the orientation of individual students' behaviors and strive to advance towards "craftsmen". 


\section{REFERENCES}

[1] Jianzhong Chen, The causes and the transformation countermeasures of the secondary vocational education[J], Chinese Professional Technology Education,2003(4).

[2] Jinnai Zhong, Discussion on "flexibility management" in student management of secondary vocational schools [J], Technological Innovation and Application, 2003, (01).

[3] Junpeng Ma, Discussion on student management in secondary vocational schools [J], Inner Mongolia Statistics, 2002(06), (8),

[4] Research on contemporary "craftsman spirit" based on Modern Apprenticeship research [J]. Yang Hongquan, Suwei. Vocational Education Forum. 2016 (16).

[5] Led by the craftsman spirit and created the future with the craftsman system Xu Guiting [J].. China Vocational and technical education. 2016 (16).

[6] Research on the contemporary value and cultivation path of craftsman spirit [J]. Li Jin. China Vocational and technical education. 2016 (27).

[7] Research on the cultivation and promotion of "craftsman spirit" under the background of supply side reform [J]. Li Hongchang. Vocational Education Forum. 2016 (16). 